\title{
HANGOK A CSENDBEN
}

\author{
Radványi Dániel \\ BSc géptervezö hallgató, Miskolci Egyetem \\ Gép- és Terméktervezési Intézet \\ 3515 Miskolc, Miskolc-Egyetemváros, e-mail: radvadani@gmail.com \\ Bihari Zoltán \\ egyetemi docens, Miskolci Egyetem \\ Gép- és Terméktervezési Intézet \\ 3515 Miskolc, Miskolc-Egyetemváros, e-mail: machbz@uni-miskolc.hu
}

\begin{abstract}
Absztrakt:
Az ember hajlamos lehet azt hinni, hogy minden érzékszerve birtokában a világot teljességgel képes észlelni. Azonban érzékeinken túl olyan dolgok is húzódnak, amelyek nagymértékben befolyásolják az életünket, anélkül, hogy ezt észre vennénk. Ezek egyszerre lehetnek hatással az érzéseinkre, elöre jelezhetnek természeti katasztrófákat, adhatnak választ akár a Bermuda-háromszög rejtélyes szerencsétlenségeire is, miközben még a szélerömüvekkel is kapcsolatba hozhatók.
\end{abstract}

Kulcsszavak: Infrahangok, frekvencia, zaj, infrahang fegyver, zajvédelem, aktiv zajcsökkentés

\section{Abstract:}

You may easily believe that with all of your senses you can detect the world entirely. However, there are some things which affects our life in many ways without being noticed. Those are able to change our feelings, sign nature disasters, give answers to the mystery of the Bermuda Triangle and can be connected with the wind turbines at the same time.

Keywords: Infrasounds, frequency, noise, infrasound weapon, noise control, active noise cancelling

\section{Bevezetés}

Az ember hajlamos lehet azt hinni, hogy minden érzékszerve birtokában a világot teljességgel képes észlelni. Valójában összehasonlítva a földi élőlények bizonyos képviselőiével, láthatjuk, hogy ilyen szempontból egészen szűk korlátok közé szorulunk. Hallásunk például a 20 - 20000 Hertz rezgéstartományába esik, miközben a rekorder a nagy viaszmoly 1 - 300000 Hertzzel, tehát nyilvánvaló, hogy van a környezetünknek egy jelentős, mérőeszközök nélkül számunka felfoghatatlan része.

Elképzelhető ezáltal, hogy érzékeinken túl olyan dolgok is húzódnak, amelyek nagymértékben befolyásolják az életünket, anélkül, hogy ezt észre vennénk. Ezek egyszerre lehetnek hatással az érzéseinkre, előre jelezhetnek természeti katasztrófákat, adhatnak választ akár a Bermuda-háromszög rejtélyes szerencsétlenségeire és a kísértetekre is, miközben még a szélerőmüvekkel is kapcsolatba hozhatók. 


\section{Az infrahang ismertetése}

Az egyik szóban forgó jelenség, amely a fent említett tényezőket összeköti, az infrahang. A hang a levegöben terjedő, térbeli, longitudinális nyomáshullám, amelynek olyan kis frekvenciájú megegyezés szerint 16-20 Hz-nél kisebb - tartománya az infrahang, amely már emberi füllel nem hallható, azonban például oszcilloszkóp segítségével kimutatható. Hullámmozgás csak rugalmas és rezgöképes közegben alakul ki.

\section{SOUND WAVE}

\section{Infrasound}

(below $16 \mathrm{~Hz}$ )

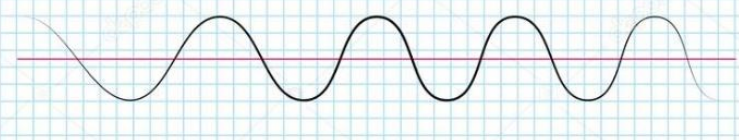

\section{Audible frequencies}

$(16 \mathrm{~Hz}-20 \mathrm{kHz})$

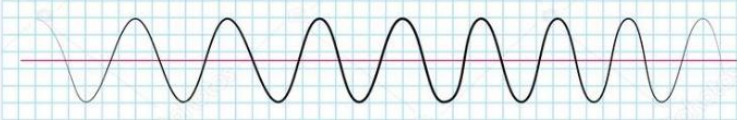

\section{Ultrasound}

(over $20 \mathrm{kHz}$ )

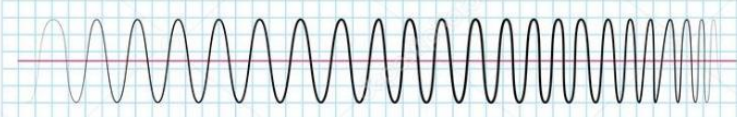

1. ábra. Hanghullámok. Fentröl lefelé: infrahang, hallható frekvenciák, ultrahang [1]

A frekvencia az időegység alatt végzett rezgések száma, a periódusidő (más néven rezgési idő) reciproka:

$$
\mathrm{f}=\frac{1}{\mathrm{~T}}[\mathrm{~Hz}]
$$

Itt a periódusidőt, vagyis a teljes hullámoszcillációhoz szükséges időt a következőképp határozhatjuk meg (oszcilláció = idöben ismétlődő változás, valamely 2 stabil állapot között):

$$
\mathrm{T}=\frac{2 \pi}{\omega}[\mathrm{s}], \quad \text { ahol } \omega \text { a körfrekvencia }\left[\frac{\mathrm{rad}}{\mathrm{s}}\right]
$$


Az infrahang tulajdonságai: legfontosabb jellemzöje, hogy közegben (légkör, víz, talaj) kevésbé csillapodik, ezáltal nagy távolságra (akár több száz kilométerre is) eljut. Másrészt, az alacsony frekvenciának köszönhetően terjedését nagyon bonyolult meggátolni, könnyen át tud hatolni akár szilárd építmények falain is [2].

A természetben a leggyakrabban olyan nagy energiájú jelenségek keltik, mint a ciklonok, földrengések, hurrikánok, szökőárak, villámok és vulkánkitörések.

\section{Az infrahang és az ember viszonya egymáshoz}

Látható tehát, hogy a természetben való létrejötte gyakran természeti katasztrófákhoz köthető, így talán nem is meglepő, hogy a talajon élö állatoknál, amelyek feltételezetten képesek érzékelni, menekülési kényszert vált ki. Hogyan reagál rá azonban az ember?

Fontos tisztázni, hogy közvetlenül nem tudjuk meghallani őket. Elképzelhető olyan helyzet, mely során számunkra teljes csend ( $30 \mathrm{~dB}$-es zajszint alatt) vesz körül minket, mégis komoly infraterhelésnek vagyunk kitéve. Ekkor rajtunk is megmagyarázhatatlan szorongás lehet úrrá.

Ezt bizonyította egy akusztikai tudós, Dr. Richard Lord által Londonban készített 750 fös kísérlet is, amely során az emberek 4 számot hallgattak meg egy koncerten, azonban a tudtuk nélkül kettőnél 17 Hz-es hangokat kevertek a zenéhez. A kísérlet után a résztvevők közel negyede számolt be extrém szomorúságról, diszkomfortérzetről, illetve aggodalomról. [3]

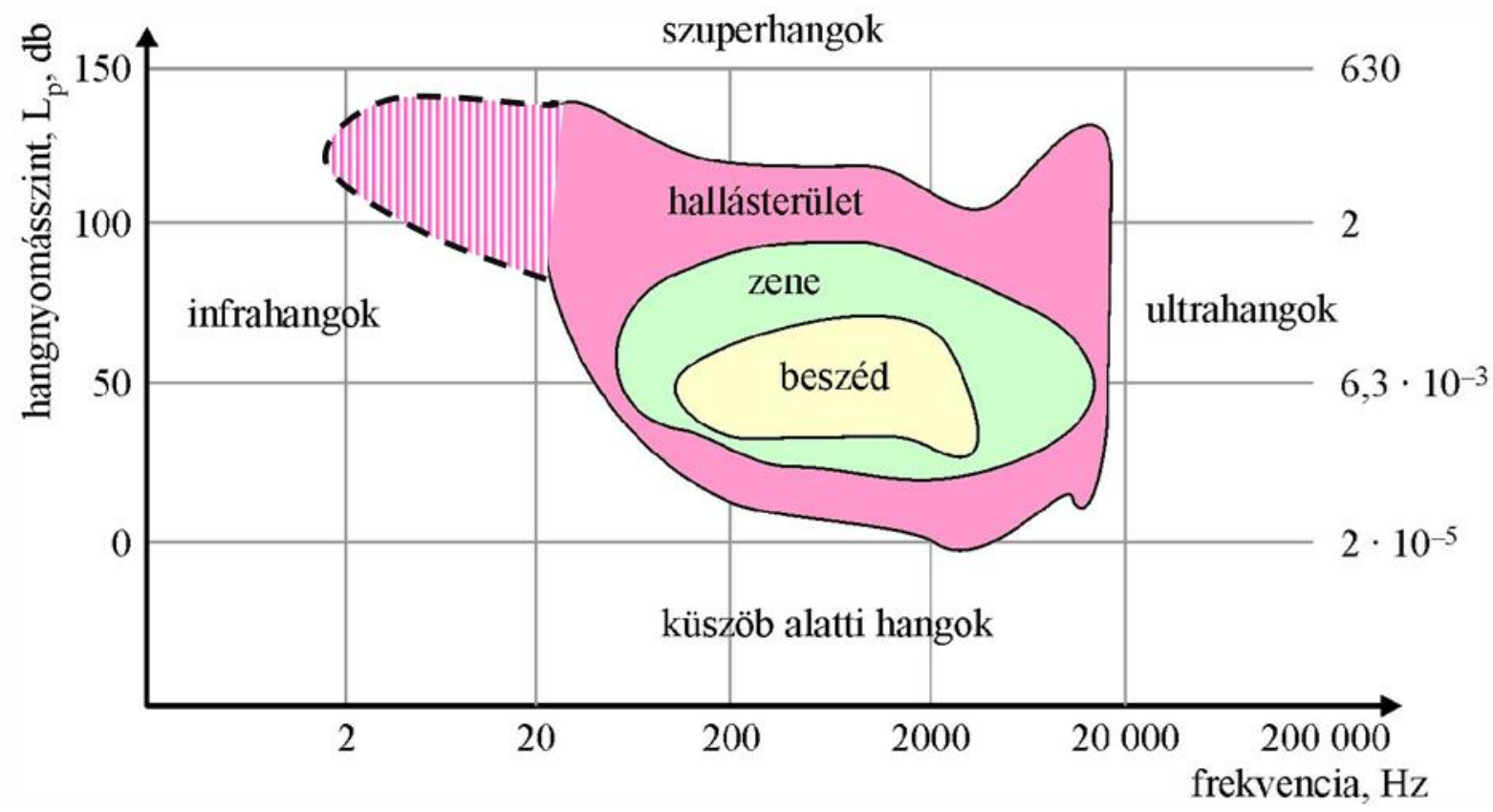

2. ábra. Az átlagos emberi hallástartomány audiogramon [4] 
Az infrahang egészségre gyakorolt hatása a hang frekvenciájától, intenzitásától és idejétől függ. Minél alacsonyabb a rezgési frekvencia, annál nagyobb hangintenzitást tudunk elviselni. Azonban huzamosabb és kellő erősségű hatás már kisebb intenzitásnál is fáradtságérzetet, szédülést, koordinációs képesség elvesztését, zavartságot, a hasi szervek, a tüdő és a középfül rezgését okozza, ezért hányinger, szív- és légzési problémák jelentkezhetnek. Egyesek szerint ezek csak $110 \mathrm{~dB}$ felett jelennek meg.

Légköri zavarok idején, a fronthatás miatt nagyobb a gépkocsibalesetek száma is, mivel az infrahangok figyelemcsökkentő hatásúak [5].

Mivel az emberi szív sajátfrekvenciája körülbelül 8 Hertz, az ilyen rezgésszámú, nagy intenzitású és teljesítményű infrahang interferenciát okoz, ami miatt sérülhet a teljes érrendszer, károsodhatnak a szervek, vagy akár le is szakadhatnak a tartószövetről, ezáltal halált is okozhat. Egyes frekvenciák keltette rezonancia hatására, $(4-6 \mathrm{~Hz})$ a szívverés amplitúdója annyira megnő, hogy az aorta megreped. A gyomor sajátfrekvenciája 2-3 Hz, a beleké 2-4 Hz, a veséké 6-8 Hz, a karoké pedig 2-5 Hz [6].

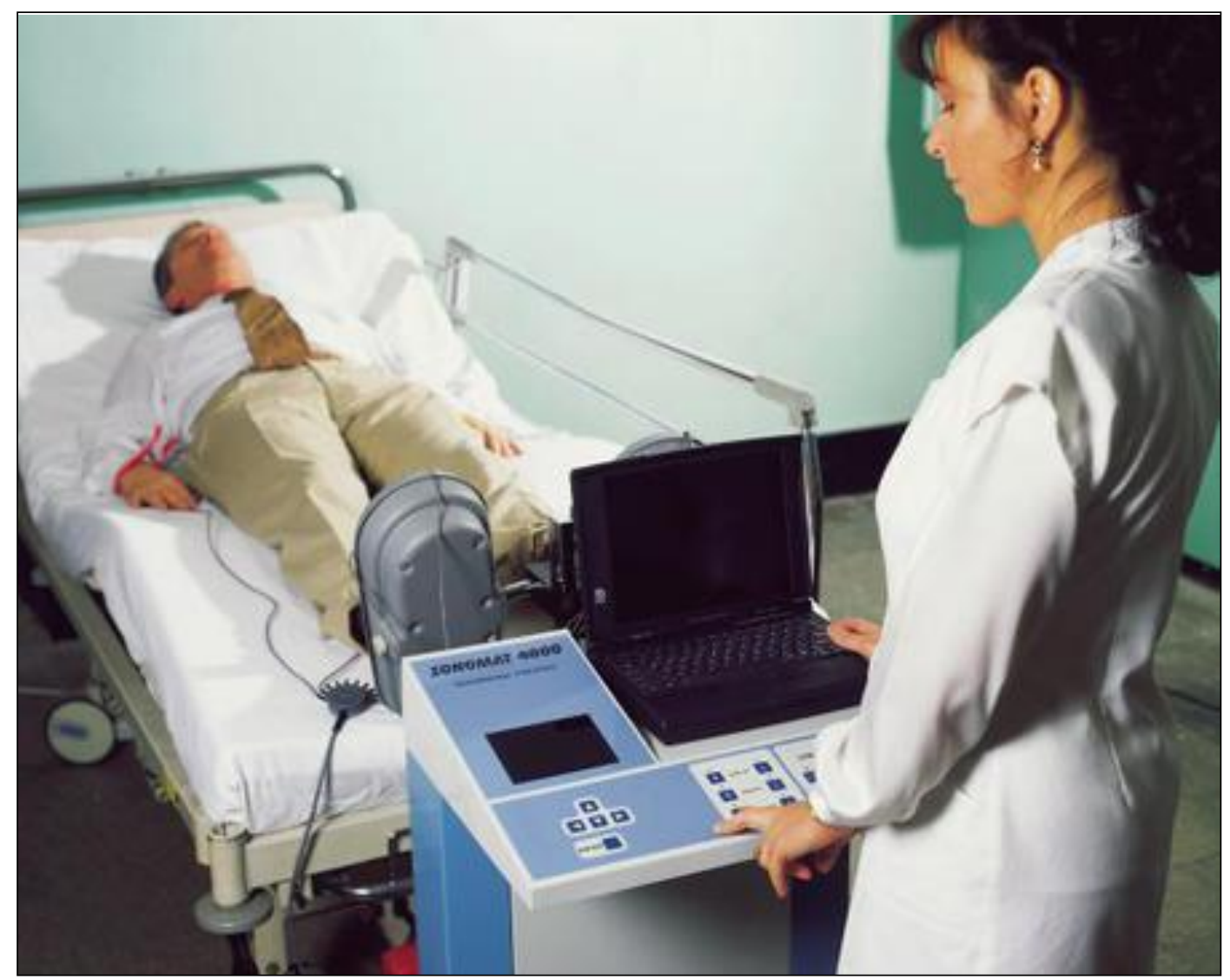

3. ábra. Sonoterápia annak alkalmazása közben [9]

Nem lennénk azonban objektívek, ha nem ejtenénk néhány szót ennek a hangtartománynak a pozitív, terápiás felhasználhatóságáról is. Egy 1997-es tanulmány szerint a $4 \mathrm{~Hz}$-es infrahangokkal végzett pneumatikus masszázs 10 napon keresztül napi 10 percen át, képes lassítani, vagy akár meg is 
gátolni a szem további romlását rövidlátás esetén iskoláskorú gyerekeknél. A $10 \mathrm{~Hz}$-en történő termovibrációs masszázs hasznos kiegészítésnek bizonyult a krónikus epehólyag-gyulladásban és parazita fertőzésben szenvedő betegek kezelésében, tekintve, hogy segíti az epehólyag ürítését. A legtöbbeket azonban a terápiás infrahang alkalmazások közül egy orvosi felszerelésekkel foglalkozó cég, az InfraMed „SonoMat” nevü terméke érinthet leginkább, amely kis frekvenciás hangok segítségével képes lehet akár az artériákat esetlegesen elzáró rögöket is szétrobbantani. [7]

Az ezt használó eljárás megálmodója dr. Nagy Lajos természetgyógyász, akit a tibeti hangtálakkal való gyógyítás ihletett meg. Magyarországon, illetve Európában és a tengerentúlon több országban is találhatunk ezen az elven müködő kezelést Sonoterápia néven, amely nem kevesebbet ígér a pácienseknek, mint az érszükület enyhítését, ezáltal csökkenő fájdalmakat járás közben, jobb terhelhetőséget, erőnlétet és a mellkasban lehetséges nyomás érzésének csökkenését. Ajánlott továbbá magas vérnyomásban, szívtáji fájdalmakban és gyakori fejfájásban szenvedőknek.

A kezelések menete rendkívül egyszerü. Ezek során számítógép által vezérelt, speciális frekvenciájú, a szívmüködés bizonyos fázisában ható, a szívfrekvenciával összehangolt hanghullám jut a szervezetbe. A hang pontos hullámhosszát EKG mérések alapján választja ki a számítógép. A kezelés átlagos időtartamát tekintve napi 10-15 percet vesz igénybe, 40-60 napon keresztül [8].

Mindezen eljárásokról elmondható, hogy viszonylag kis hangintenzitás-szinttel alkalmazzák - amely gyakran $70 \mathrm{~dB}$ körüli értéket jelent.

\section{A ,kísértet frekvencia"}

Az infrahangokat szinte mindennel összefüggésbe hozták már. Korábban is számtalan tudós feltételezte a mára igazoltnak látszó tényt, hogy a "szellemjárta" helyeken ezek a hangok váltanak ki olyan érzést, amelyet az emberek a kísérteteknek tulajdonítanak: rejtélyes körülmények között elalvó gyertyák, furcsa érzések és borzongás. Ezeket a jelenségeket aligha a kísértetjárta házak szellemei okozzák, sokkal inkább egy rendkívül alacsony frekvenciájú hang [10].

Vic Tandy, a Coventry University professzora egy véletlen felfedezése óta úgy véli, egyes „szellemlátásokért” a 19 Hz körüli infrahangok lehetnek a felelősek.

Egyik éjszaka egy közismerten kísértetjárta laboratóriumban dolgozott Warwickban, amikor hirtelen nyugtalanná vált, és a szeme sarkában egy szürkés foltot vett észre. Amikor odafordult, a folt eltünt. Másnap a vívótőrjét egy satuba fogta be, és azt tapasztalta, hogy a penge hevesen rezegni kezd. A vizsgálat fényt derített rá, hogy az elszívó berendezés ventilátorának frekvenciája $18,98 \mathrm{~Hz}$ volt, a szoba mérete pontosan megfelelt e hanghullám hullámhossza felének, az asztal középen állt, így ott állóhullám alakult ki, ez hozta rezgésbe a pengét [11].

A NASA egyik anyaga szerint a szem rezonanciafrekvenciája $18 \mathrm{~Hz}$. Az említett helyen ilyen frekvenciájú rezgés keletkezett, és ezt Tandy a szem rezgése következtében szürke foltként érzékelte [12]. Később Tandy megjelentetett egy tanulmányt The Ghost in the Machine címmel (magyarul: „A szellem a gépben"), miután tovább vizsgálta ezt a jelenséget [13]. A professzor felmérte az olyan közismerten kísértetjárta helyeket is, mint például a coventryi katedrális mellett található Tourist Information Bureau alagsora és az edinburgh-i kastély, amelyeknél mindkét esetben az infrahangok magas szintjét mérte. 


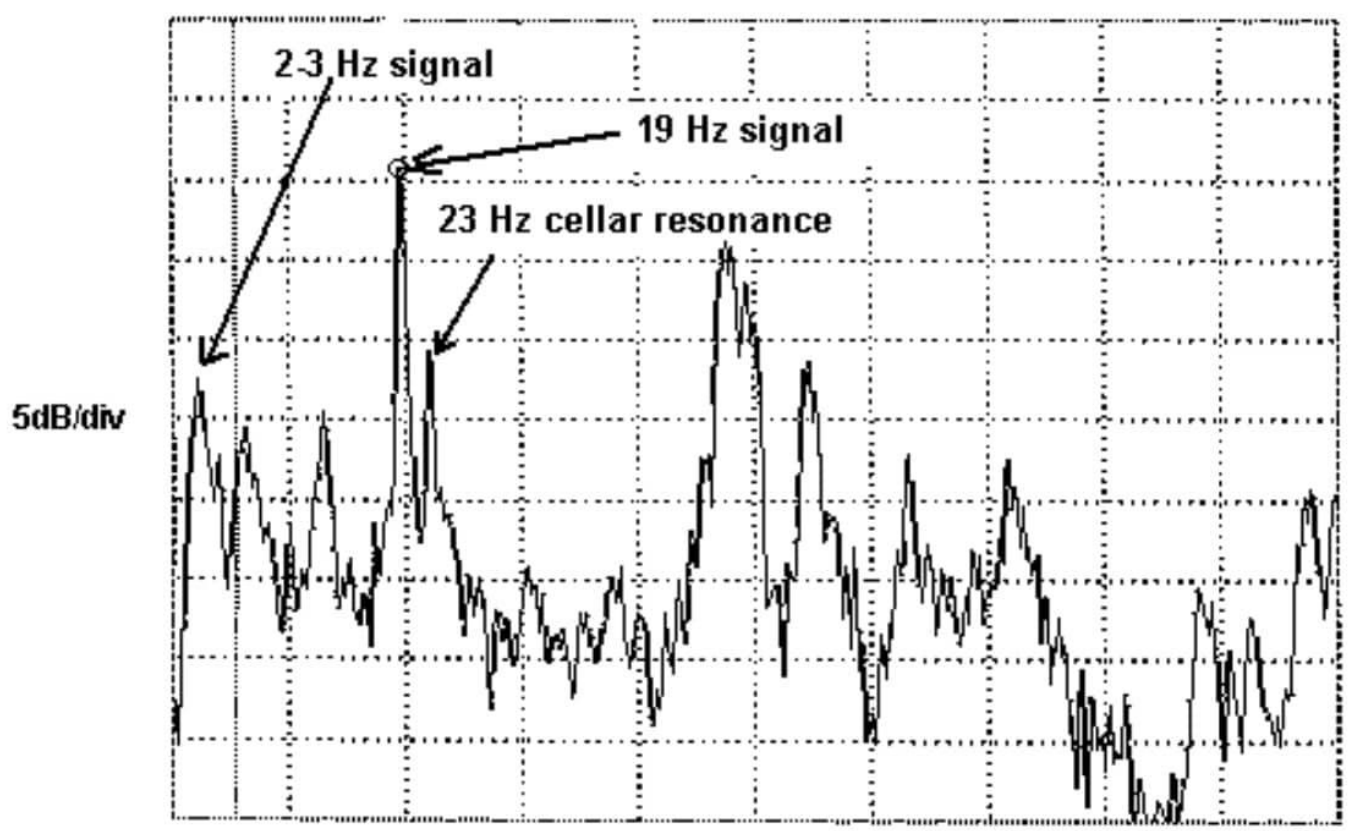

Frequency in $\mathrm{Hz} \quad 10 \mathrm{~Hz} / \mathrm{div}$

4. ábra. Tandy Tourist Information Bureau alagsorában végzett méréseinek eredménye [14]

\section{A mozivászon mögött}

Az eddig leírtak szerint tehát létezik egy hangfrekvencia, amely észrevétlenül félelmet kelthet az elszenvedőjében. Természetesen egy ilyen jelenséget a szórakoztató ipar sem hagyhatott kiaknázatlanul. A hangrendszerek fejlödésével a filmkészítők is egyre több eszközt kaptak az élmény kiterjesztéséhez, amelyek felhasználásában többek között a horrorfilmek úttörőnek számítottak.

Frank Warner, neves hangszerző, aki egyebek mellett a Rocky filmek készítésében is közremüködött, a '70-es és '80-as években rengeteg féle hangot, többek között elhangolt dobverőket, továbbá lelassított elefánt hangokat használt (ismert, hogy az elefántok infrahangokkal kommunikálnak), hogy a különböző jeleneteket minél zavarba ejtőbbé tehesse.

A digitalizáció megnyitotta a lehetőséget a hangtervezés előtt, ezáltal elérhetővé téve azt a kis költségvetésü produkciók számára is. A francia filmkészítő, Gaspar Noé elismerte, hogy infrahangokat használt olyan alkotásaiban, mint mondjuk a „Visszafordíthatatlan” és a „Parajelenségek” címü filmek. Voltak olyanok is, akik transzformátorok, légkondicionálók és egyéb alacsony frekvenciákat is keltő eszközök hangját vették fel, hogy azt felhasználhassák.

„Nem hallod, de mégis megborzongsz. Egy jó moziban, amely rendelkezik mélynyomóval, lehet, hogy nagyobb rémület lesz rajtad úrrá a hang hatására, mint attól, ami a képernyőn történik." - nyilatkozta egyszer Gaspar Noé [18].

Természetesen mindezeknek csak akkor van értelme és hatása, ha megfelelö hangrendszeren játszák le, de ez napjainkban már otthon is egyre kevesebbeknél ütközik akadályba a házimozik elterjedésével. A legvalósághübb élményt persze még továbbra is a mozitermekben tapasztalhatjuk. 


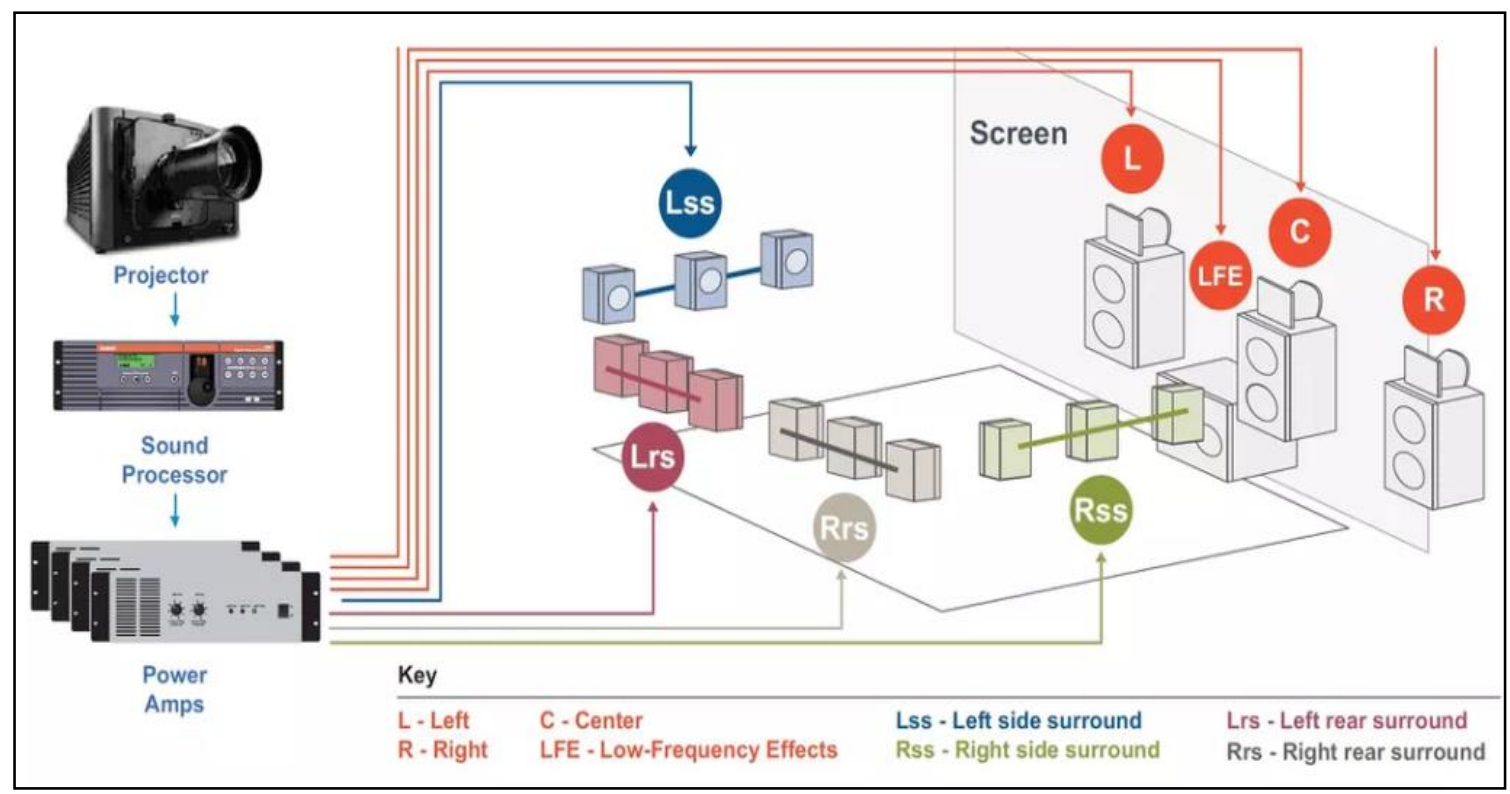

5. ábra. 7.1-es hangrendszer vázlata egy moziteremben [15]

Számos hangszórót használnak, viszont hangkeltésnél nem csak egy szólal meg, hanem egymás mellett egyszerre több is.

Mindezek müködését jól példázza egy Daniel T. Blumenstein nevű kutató által lefolytatott kísérlet, mely során a közönségnek teljesen ártalmatlan és hétköznapi képsorokat mutatott, azonban állatok által kibocsátott hangokat vágott alá (például vészhívásokat, visításokat, vonyításokat), amelyek többnyire nagy hullámhosszal rendelkeznek, ezáltal kis frekvenciával, bár ezek nem minden esetben esnek az infra tartományba. A nézők nem tudták megmagyarázni, de ijesztőnek találták, amit láttak. A kis frekvenciák és állati hangok kombinációjának használatát fedezhetjük fel például „Az ördögüző” és „Ragyogás” címü alkotásokban is [16] [17].

Egyre gyakrabban képezi a filmek célját, hogy a publikumot egy érzelmi utazásra vigye. Egy jó rendező dolga, hogy elhitesse a közönséggel, hogy ami a képernyőn történik, az szervesen és logikusan kapcsolódik a történethez, amelybe be van vonva. Ehhez szükség van a megfelelö zenei aláfestésre is, amelyben kicsit alattomosabb módon segítséget nyújthatnak a kis frekvenciás hangok is, amennyiben a megfelelő kontextusban használják, mondjuk egy ijesztő jelenet előkészítésére, vagy szimplán a feszültség fokozására, így napjainkra egyre több alkalommal alkalmazzák [18].

\section{6. Életmentés infrahangokkal}

Mivel a megmagyarázhatatlan emberi félelmekre, vagy esetleg állatok viselkedésének megfigyelésére nem alapozhatjuk ezrek biztonságát, létrehozták a megfelelő müszereket, amelyekkel mérhetővé váltak a természeti katasztrófákat előrejelző infrahangok. 


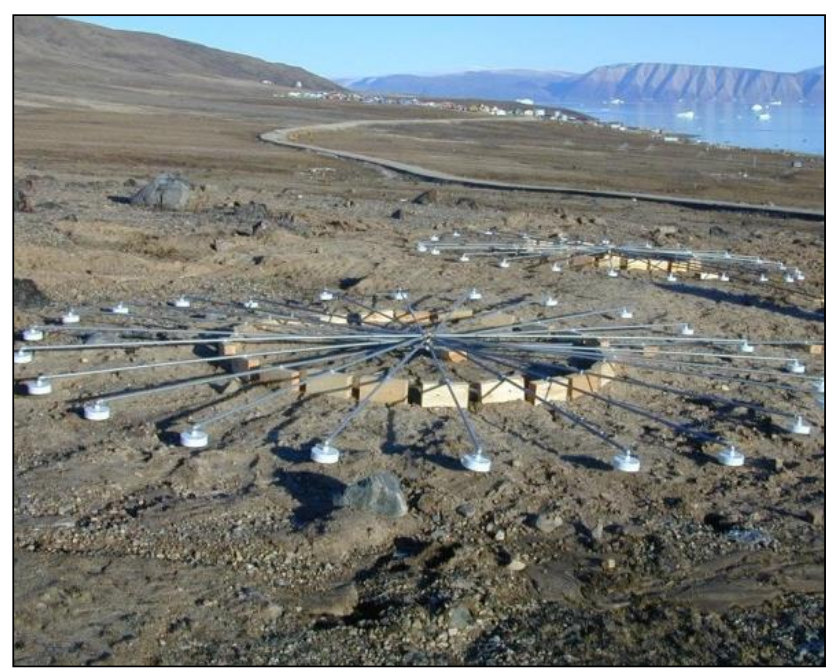

6. ábra. Infrahang érzékelö állomások [19]

Az olyan országokban, amelyek pusztító cunamiktól szenvednek (Japán, Fülöp-szigetek, Malajzia, Thaiföld, Indonézia és mások), a tudósok cunami detektáló rendszereket alakítottak ki.

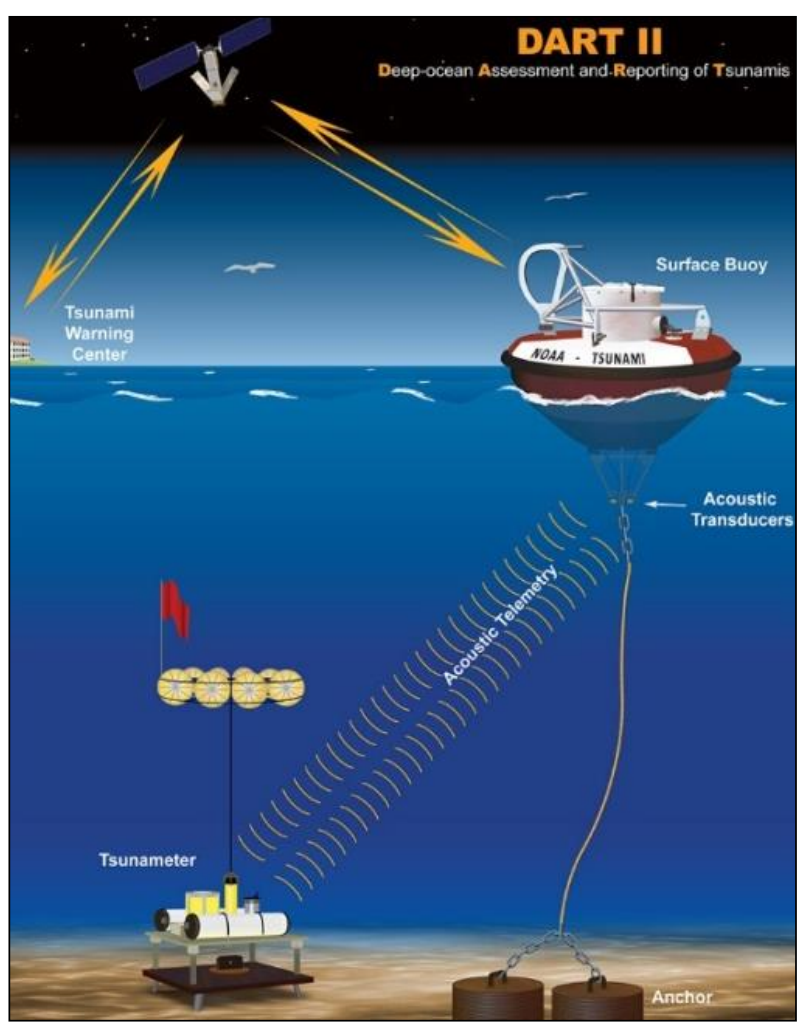

7. ábra. A DART rendszer müködése [20] 
Eltekintve a tengerpartra telepített szeizmikus állomásoktól, önálló DART (Deep-ocean Assessment and Reporting of Tsunami) állomások hálózata is telepítésre került. Ez utóbbiak múholdak segítségével küldik az információkat a feldolgozóközpontokba, és fogadják onnan az esetleges parancsokat.

Habár az anyagi veszteségeket nem tudják meggátolni, az ilyen rendszerek esélyt teremtenek a lakosoknak a katasztrófa bekövetkezése előtt elmenekülni, ezzel reményt adva, hogy a szökőárak nem fogják emberéletek ezreit követelni többé.

A tornádók is akár már 1 órával a létrejöttük előtt jelezhetők ilyen módszerekkel [21]. Hasonló elven mérhetőek a szeizmikus hullámok is, amelyek olyan rengéshullámok, amelyeket földrengések vagy esetleges mesterséges robbantások kelthetnek.

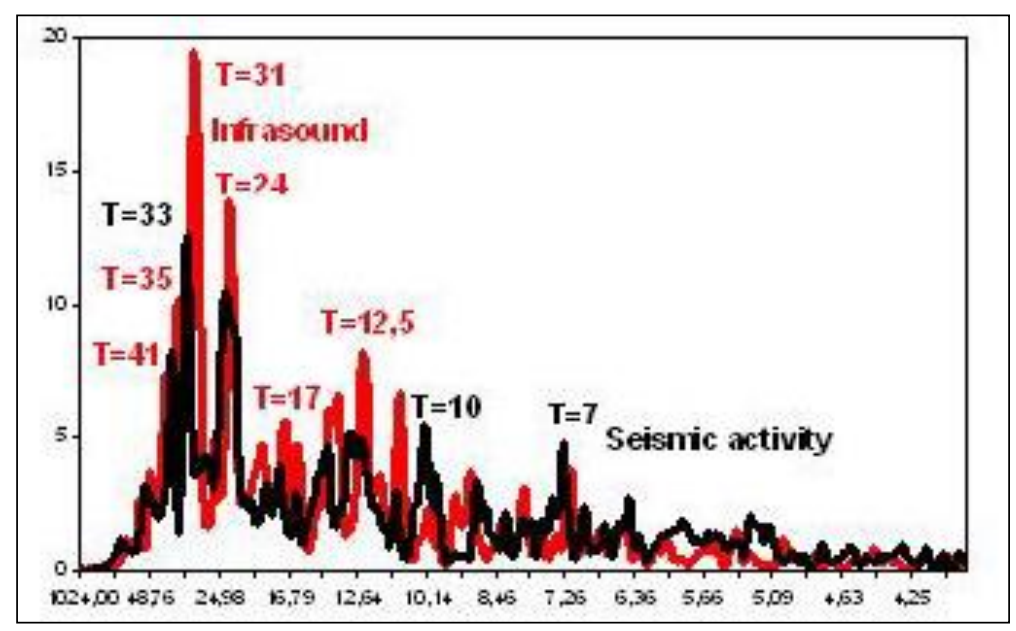

8. ábra. Szeizmikus aktivitás és infrahangok összefüggése 1997 és 2000 között (maximumok) [3]

(Piros vonal: infrahangok, Fekete vonal: szeizmikus aktivitás)

Az infrahang monitorozás szerves része az Átfogó Atomcsend - a nukleáris robbantások végrehajtását tiltó - egyezmény ellenőrző rendszerének, amely képes a Földön bármilyen nukleáris robbanást detektálni, történjen az az atmoszférában, a föld vagy víz alatt. A kis frekvencia figyelése azért is kiváló erre a feladatra, mert ezek a hanghullámok nagy távolságokig terjednek, mialatt csak kissé szóródnak szét [6].

\section{Kisfrekvenciás hadviselés [22]}

Ezzel elértünk a harcászat területéhez. Természetesen, mint szinte minden fizikai jelenséget, ezt is megpróbálták harci eszközök készítésére felhasználni, mégpedig sikerrel. Az infrahang fegyver alkalmazásának előnyös oldala, hogy a kis frekvenciájú hanghullámok terjedését nehéz megakadályozni vagy csökkenteni, és terjedési sajátossága, hogy áthatol minden szilárd anyagon. A készülék az élőerőt támadja, technikai eszközökben nem okoz kárt. Ezeket az eszközöket ún. nonletális (halált nem okozó) fegyvereknek nevezzük. 
Hatására a célszemély mentális képességei nagymértékben csökkennek, megnő reakcióideje, szükül a látótere, nyugtalanságot, szédülést, fejfájást, émelygést és görcsöket okoz, de előidézhet légzési nehézségeket és szélsőséges esetben epilepsziás rohamot is. Mint az előzőekben is kifejtettük, akár belső sérüléseket is okozhat. Az infrahang alkalmazásának további előnye, hogy nem hallható, ezért mire észleljük annak hatásait, addigra a támadás elérte a célját. Hátránya a technológiának, hogy müködtetéséhez nagy energia szükséges. Megvalósításának egyik ismert változatát, az Acoustic Heterodyne csövet mutatja be az ábra:

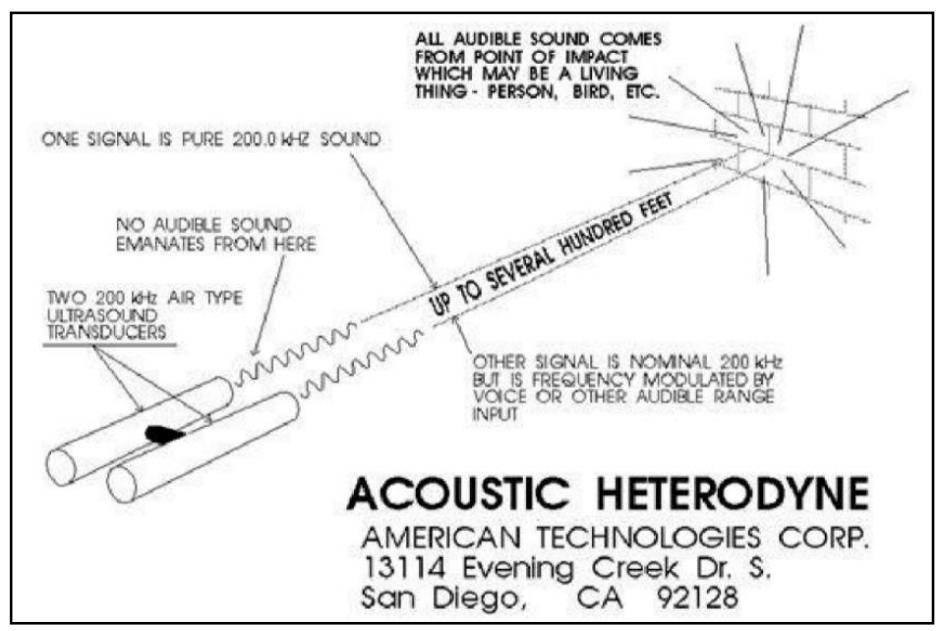

9. ábra. Acoustic Heterodyne csö [22]

A forrásnál a csövekben közel $200 \mathrm{kHz}$ frekvenciájú jeleket állítanak elő. A célpont maximum $100-$ 150 m távolságban helyezkedik el, ahol a két cső által kibocsátott jelek interferenciájából létrejön a 7 Hz körüli különbségi frekvencia, amely vizsgálatok és kísérletek alapján a már ismertetett negatív hatásokkal hat az emberi szervezetre. Mindezek mellett jól szabályozható a kibocsátott jel intenzitása, így nem csak a harctéren, de például egy tüntetés feloszlatása során is bevethetö, ahol nem feltétlenül cél a résztvevőkben kárt tenni.

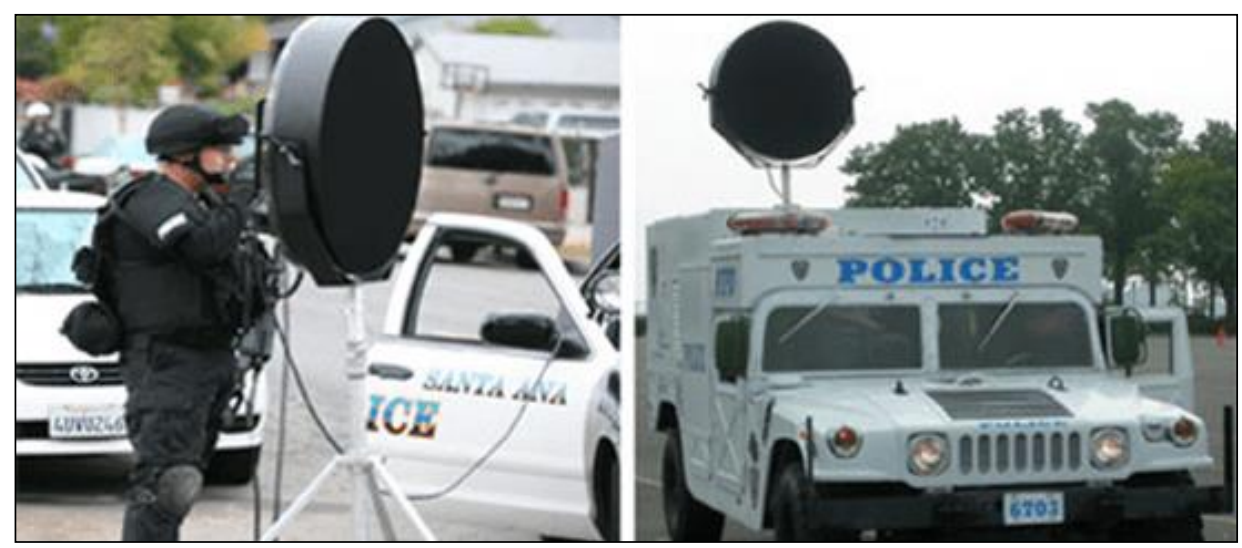

10. ábra. Infrahang fegyverekkel felszerelt rendörök [23] 


\section{A „háromszögek" rejtélye}

Visszatérve a misztikumok vonalára: csak a közelmúlt alapos oceanográfiai kutatásai derítettek fényt arra, hogy a Bermuda-háromszögként elhíresült tengeri területen, a térség sajátos meteorológiai és áramlási viszonyai miatt, időnként rendkívül erős infrahangok képződnek.

Ez a felfedezés számos, az övezetből ismert nyomtalan eltünés rejtélyére is magyarázatot adhat, és nem csak ezen a területen.

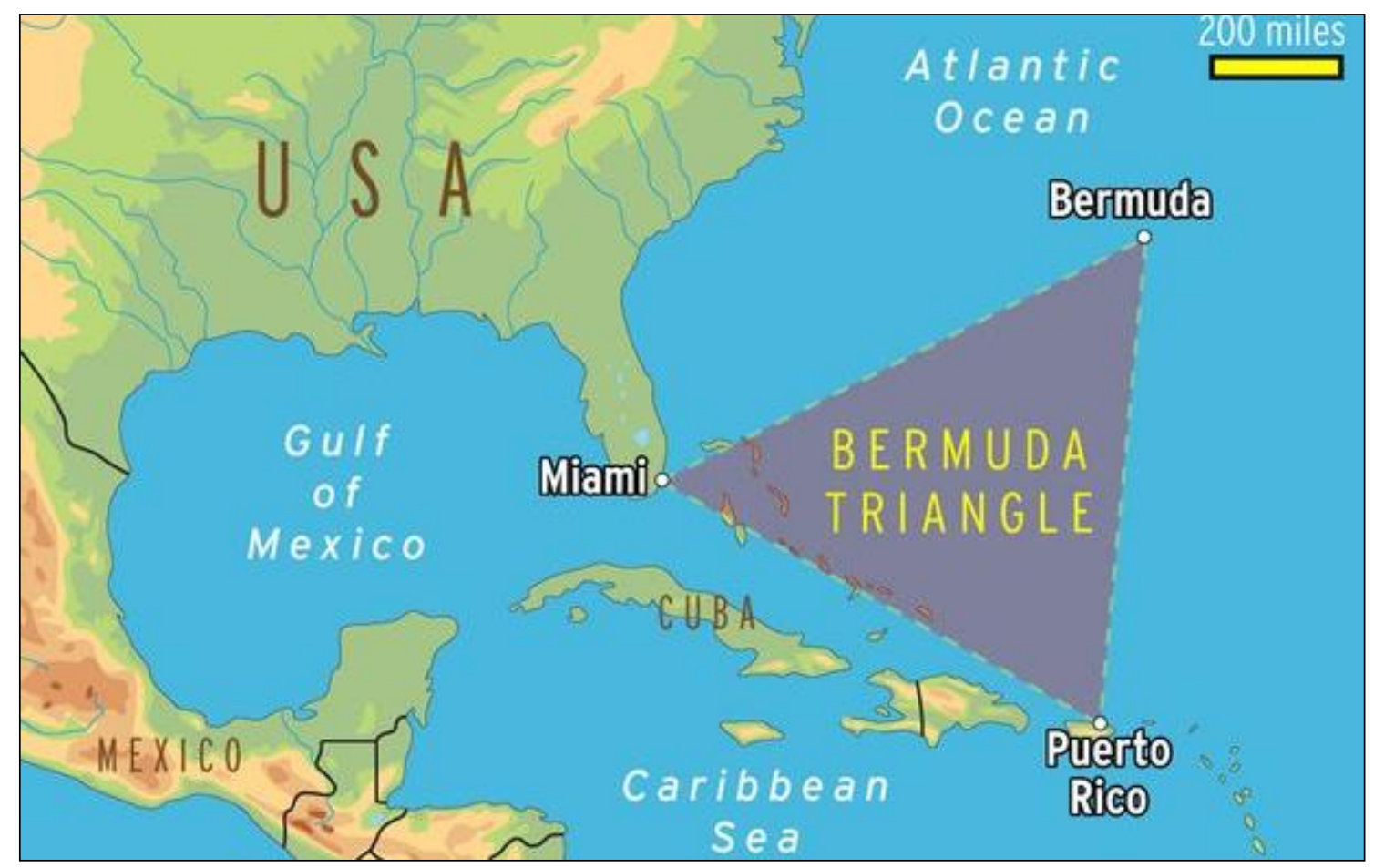

11. ábra. A Bermuda háromszög [24]

Vlagyimir Azsazsa orosz oceanográfus vetette fel elöször, hogy az itt különösen gyakori heves viharok illetve hurrikánok, valamint a sajátos áramlási rendszer következtében a tengervíz hirtelen hőmérséklet változása esetenként kifejezetten erős infrahanghatást gerjeszt, és ez szerepet játszhatott a Bermuda-háromszögből ismert hajó-, illetve repülőgép szerencsétlenségekben.

$\mathrm{Az}$ amerikai Nemzeti Óceán- és Légkörkutató Intézet (National Ocean and Atmospheric Administration, NOAA) hullámterjedéssel foglalkozó kutatói egyetértenek Azsazsa hipotézisével.

A megfigyelések azt bizonyítják, hogy a térségben a Golf-áramlat miatt nagyon élesen változik a hőmérséklet, és az eltérő hőmérsékletü víztömegek határán megnőhet az infrahangok intenzitása.

A trópusi viharok körzetében pedig rendkívül erős, és akár több ezer kilométeres távolságra eljutó infrahangok képződhetnek. Az erős infrahanghatás megzavarhatja a repülőgépek navigációs müszereit és a legénységet is [25]. 
Gyakorlatilag ugyanez igaz a nálunk kevésbé ismert, de hasonló paranormális jelenségekkel bíró „Sárkány- háromszög” nevű területre a Csendes-óceánon, Tokiótól délre, amelyet „Ördög-tengernek” is neveznek.

Számos baleset és legenda füződik hozzá már a 12. század óta, elsősorban nyomtalanul eltűnő hajóké, majd később repülőké. A keresztülhaladók megmagyarázhatatlan félelemről és azonosíthatatlan tárgyak észleléséről számoltak be. Természetesen az itt fellelhető meleg és hideg áramlatok találkozása, illetve a víz alatti vulkánok már önmagukban is veszélyt jelentenek, azonban infrahang képző hatásuk is magas [27].

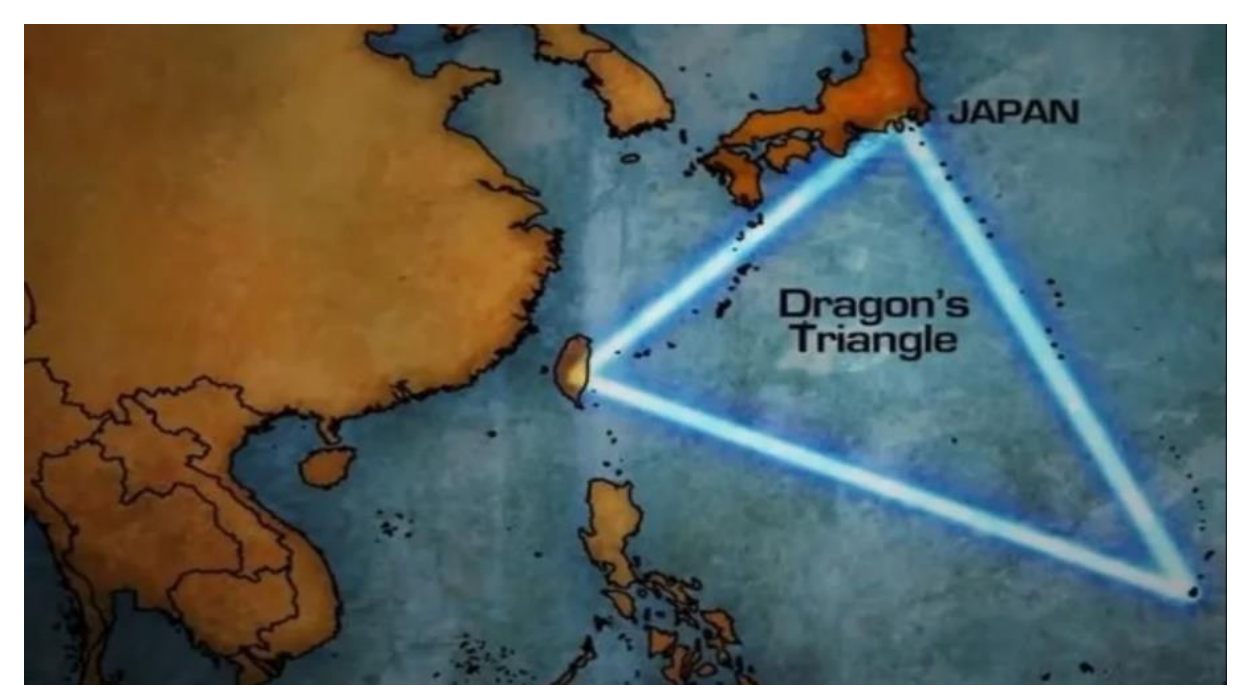

12. ábra. ,,Sárkányok háromszöge” [26]

\section{Az akusztikus szmog}

Az emberiség akaratlanul már az első megalitikus építmények felállításával (ilyen akár a Stonehenge is), illetve zárt tereket magukban foglaló városok alapításával mesterséges infrahang generátorokat készített, amelyek passzív rezonátorokként, illetve a szél által infrahang generátorokként viselkednek. Ezeknél némileg nagyobb mértékben állították elő őket az első víz- és szélmalmok, amelyek hatása még mindig nem volt olyan jelentős, mint napjaink gépei, azonban ennek ellenére több kultúrából is fennmaradtak a molnárokkal és kovácsokkal kapcsolatban konkrét indok nélküli, de negatív hangvételü legendák, amely talán még inkább érthetővé válik annak tudatában, hogy utóbbi minden kalapácsütésnél infrahangokat keltett, ezek pedig akaratlanul is rossz érzéseket váltottak ki a középkor emberéből [5].

Napjainkban az infrahangok a legkülönfélébb helyeken érhetnek minket. A modern világ „melléktermékeként” be kell vezetnünk az akusztikus szmog fogalmát. Az irodákban például ennek gyakori forrása a ventilátor és a légkondicionáló. Csupán minimális erősséggel, de a személyi számítógépek is bocsátanak ki infrahangokat, amennyiben bennük gondatlanul megtervezett, rossz minőségü ventilátor található. Ezek a turbulencia és vibráció hatására megközelítőleg $5 \mathrm{~Hz}$-es hangot generálnak, amely azonos az agyunk belső frekvenciájával (3-6 Hz), ezért egyéb, hangoktól független 
hatások mellett ez is közrejátszhat a sokaknál tapasztalt idegi kimerülésben, nyugtalanságban, fejfájásban vagy szédülésben a gyakori vagy hosszú időn át tartó számítógép használatot követően [28].

Az iparban használatos gépek közül is számos gerjeszt infrahangot. Keletkezik hangrobbanás vagy közönséges robbanás esetén is, például dízelmotor müködése során, szélturbina közelében vagy nagyméretü basszus hangsugárzóban, így az egészségre káros infrahangok forrása lehet minden, lassú ritmusban dolgozó berendezés vagy akár a jármüvek dübörgése is.

\section{A szélturbina: barát vagy ellenség?}

A növekvő számú szélturbina parkok kapcsán is felvetődött a kérdés, hogy az általuk kibocsátott infrahangok, amelyek jelenlétét már bizonyították, vajon veszélyesek-e az emberre?

A turbinák müködésük során több módon is generálnak infrahangokat: elsősorban a lapátok mellett örvénylő levegő által, illetve a lapáttőnél-, és bizonyos kialakításoknál a sebességváltóban keletkező mechanikus zajok részeként.

Az első konstrukciók a '80-as években még kifejezetten nagy zajszennyezést okoztak, de ezt napjainkra már jelentősen sikerült csökkenteni, például a lapátok kialakításának optimalizálásával, illetve azok ideálisabb elhelyezésével [29].

Egyes tudósok állítása szerint a szélerőmüvek közelsége az ott élőkre olyan káros hatásokkal lehet, mint a daganatos megbetegedések, illetve egyéb különböző rendellenességek. Összefoglalva ezt „szélturbina szindrómának” nevezték el [30].

Persze ilyen súlyos hatások nem kerültek nagy mennyiségben dokumentálásra, ami nem meglepő, hiszen példának okáért sejtmutáció kiváltására aligha rendelkeznek kellö energiával ezek a hanghullámok, azonban annál gyakoribb jelenség, hogy a széleröművek közelében élők többen panaszkodnak krónikus alvászavarra, stresszre és esetenként zúgó fülre is, melyek hatására többen el is hagyták otthonukat. Az ilyen esetek inspirálták több olyan csoportosulás létrejöttét is, mint például a kandadai székhelyü Észak-Amerikai Platform a Szélenergia Ellen (North American Platform Against Wind Power, NA-PAW), amelynek tagjai tiltakoznak a szélerőmüvek telepítése ellen [31].

Az erőmüvektől való biztonságos távolság biztosítására a világon szinte mindenütt vannak ezt meghatározó rendelkezések, amely általában legalább 300 métert jelent, de ehhez képest Magyarországon extrém szigorú a szabályozás, így csak a lakott területektől távol lehet ezeket telepíteni. Ez a hallható hangok tekintetében müködik is, hiszen a szélturbinák közelében mérhető 100 $\mathrm{dB}(\mathrm{A})$ maximális hangnyomás $100 \mathrm{~m}$ távolságban már $60 \mathrm{~dB}(\mathrm{~A})$ értékre csökken [32], a német Max Planck Társaság mérései szerint azonban a kibocsátott kis frekvenciás hangok még $20 \mathrm{~km}$-rel távolabb is kimutathatóak voltak [33].

Más kutatók viszont nem találtak kapcsolatot a szélerőművek és az említett kóros állapotok megjelenése között, azon kívül, hogy akik többet olvastak vagy hallottak a szindrómáról, azok nagyobb eséllyel fedezték fel magukon a tüneteket - attól függetlenül, hogy volt-e a közelükben turbina. A Dán Környezetvédelmi Ügynökség (Danish Enviromental Protection Agency) is végzett kutatást a témában. Azt találták, hogy a szélerőmüvek által kibocsátott kis frekvenciás zaj messze az érzékelhető és egészségkárosító küszöb alatt marad, általában nem lépi át a $85 \mathrm{~dB}(\mathrm{~A})$ szintet [34]. 
Nincs tehát egységes álláspont ezen erőművek káros infrahang hatásai kapcsán, de ebben közrejátszik, hogy minden ember különböző mértékben érzékeny erre a hangtartományra, illetve sokat számít az adott turbina kialakítása és távolsága a lakóövezettől.

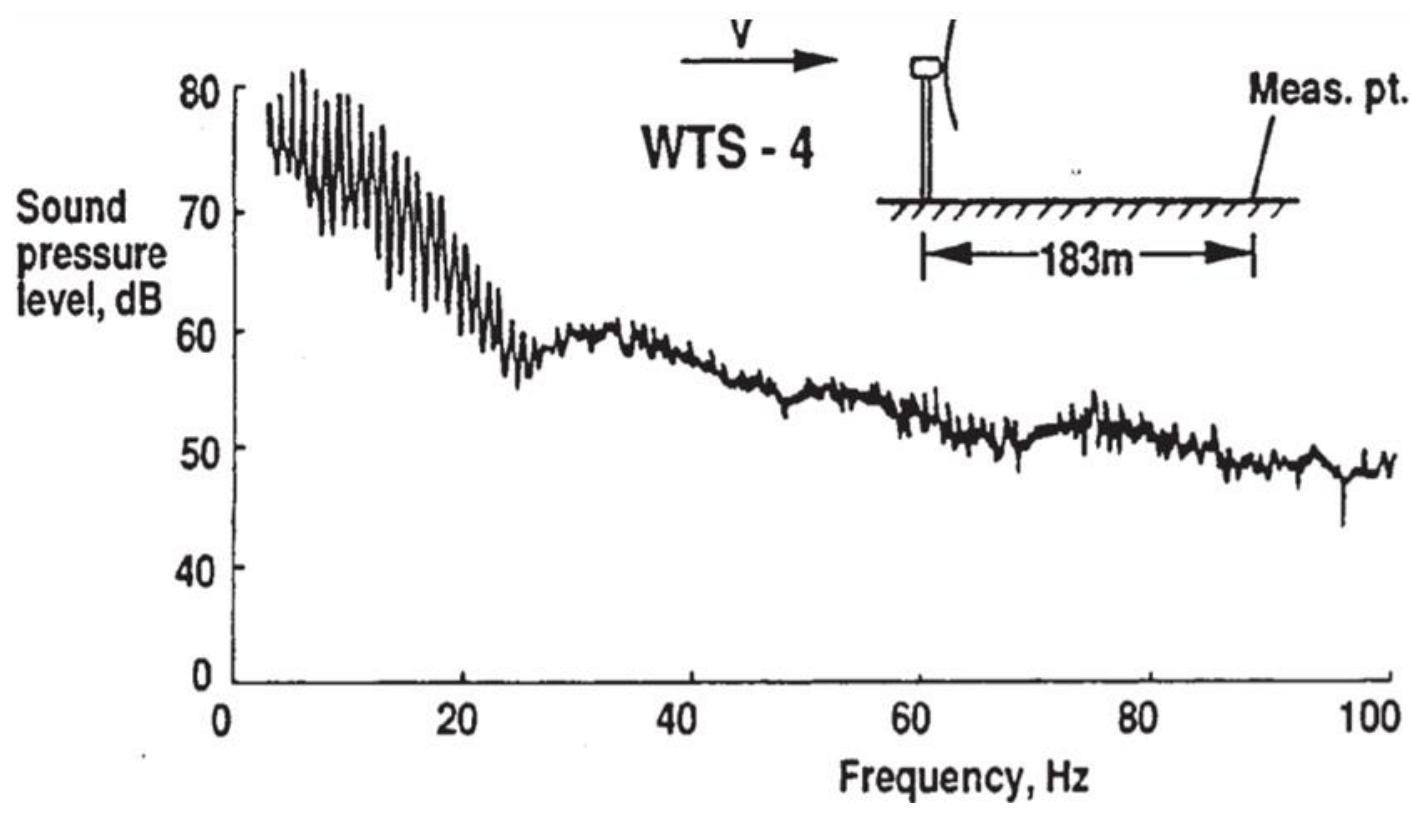

13. ábra. A szélturbinától 183 m-re felvett hangspektrum, hangnyomásszint és frekvencia függvényében. [34]

\section{Hallani a hallhatatlant}

Ez a tanulmány azzal kezdődött, hogy az infrahangokat nem vagyunk képesek meghallani. Egy bekezdés erejéig látszólag ennek ellent fogunk mondani.

Jobb minőségü fül- és fejhallgatók specifikációinak tanulmányozásakor gyakran találkozhatunk azzal, hogy az eszköz frekvencia-átvitele szélesebb, mint az emberi hallástartomány.

Mi értelme azonban többet fizetni egy fülhallgatóért, miközben az emberi hallástartományt egy olcsóbb is könnyedén lefedi? Röviden a válasz erre, hogy halljuk a tartományon kívül eső hangokat is, csak nem a szokványos értelemben. Az agyunk ugyanis képes arra, hogy észleljük a hallástartományon kívül eső frekvenciákat is.

A francia matematikus, Joseph Fourier tétele kimondja: minden összetett (periodikus) hangot felírhatunk véges (vagy végtelen) számú szinuszos összetevő összegeként. Ez érvényes a zenei hangokra is, amelyek annyiban speciálisak a szabálytalan (zörejes) hangokhoz képest, hogy az őket alkotó szinuszos hangok frekvenciái egymás egész számú többszörösei [36].

Konkrét példán keresztül ez a következőképp müködik: szintetizálunk három hangot, egy 75 , egy 150 és egy 225 Hertzeset. A $75 \mathrm{~Hz}$ lesz az alaphang, a másik kettő (amelyek egész számú többszörösei ennek) pedig a felhangok. Az alaphang adja meg, hogy milyen mélynek halljuk az adott hangot. 
Biológiailag úgy vagyunk kódolva, hogy ezt az információt, azaz, hogy egy összetett hangnak melyik a legmélyebb frekvencia-összetevője, mindenképp észlelni akarjuk.

$\mathrm{Az}$ alaphang, valamint a felhangok szoros összefüggésben vannak, ugyanis a felhangok minden esetben az alaphang egész számú többszörösei. Éppen ezért, ha magát az alaphangot nem, csak a felhangjait halljuk, akkor az agyunk ki tudja következtetni, mi a felhangok legnagyobb közös osztója, tehát az alaphang. Még abban az esetben is, ha az egyáltalán nincs jelen az összetett hangban, és akkor is, ha az alaphang már az infra-tartományba esik.

Ha tehát a most előállított 150 és 225 Hertzes hangokat együtt játszom le, akkor érzetileg meg fog jelenni a nem létező $75 \mathrm{~Hz}$-es alaphang is. Ugyanezt alkalmazzák például az orgonisták is. Bizonyos mély hangok lejátszásához akkora sípra lenne szükség, amely be sem fér a templomba, így helyette inkább egyszerre nyomják le a követö felharmonikusokat, a többit már az agyunk elintézi.

Minél nagyobb egy fejhallgató frekvenciaátviteli képessége, annál több ilyen felhangot tud megszólaltatni, annál komplexebb lesz az élmény, és nem mellesleg annál valósághübb. Az tehát, hogy a hallástartományunknál egy fejhallgató szélesebb spektrumot fed le, egyáltalán nem olyan butaság, hiszen a zenehallgatásban legalább annyira részt vesz az agyunk, mint a fülünk. Amit pedig nem tud az utóbbi, azt a tudatunk kipótolja [35].

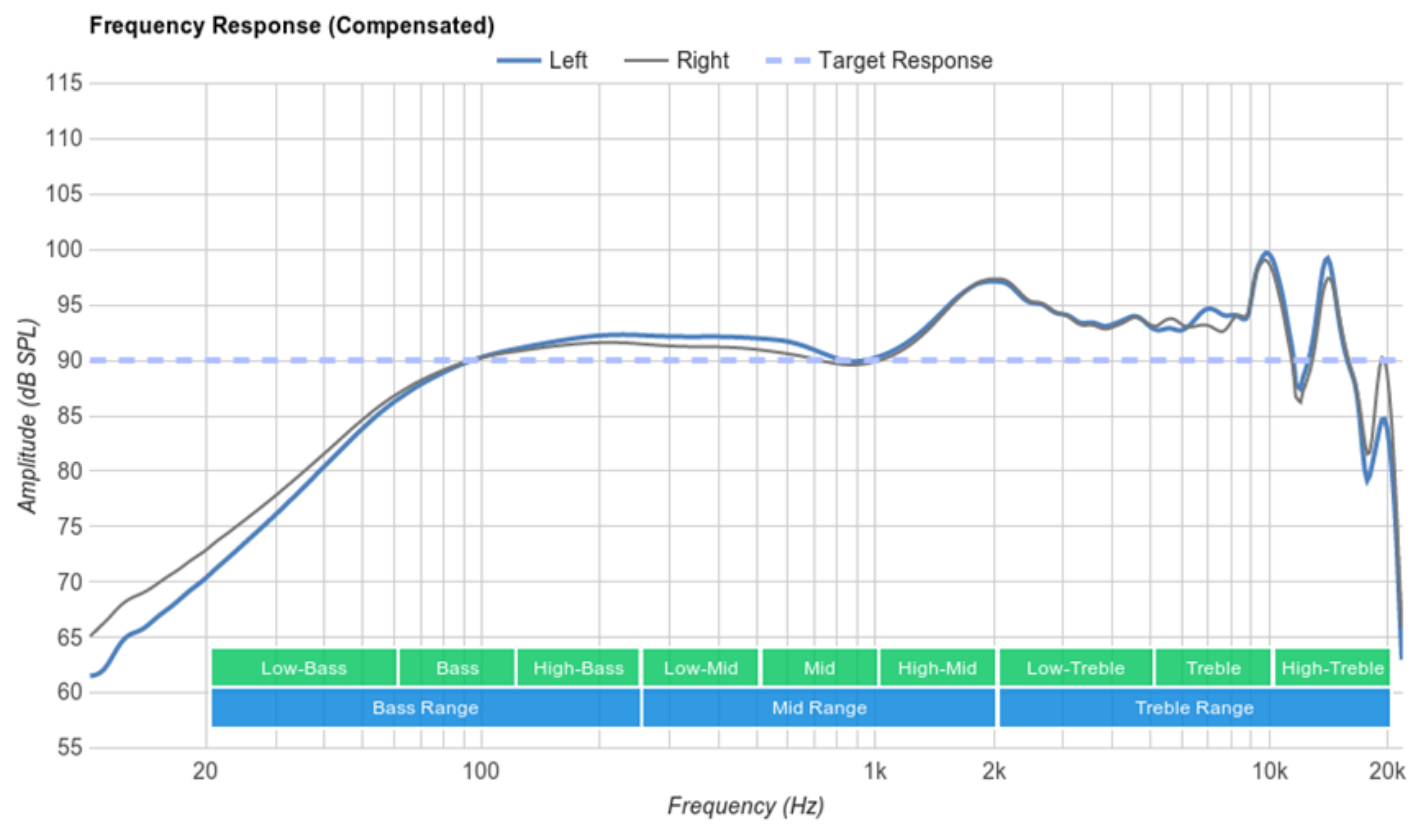

14. ábra. Apple Airpods fülhallgató frekvenciamenete [35]

Nem ez az egyetlen különleges jelenség, amelyre a hangok képesek. Míg a felhangok az alhang többszörösei, addig a szubharmonikusok ennek ellentéteként olyan harmonikus alsó hangok, melyek rezgésszáma az alaphangnak egész számú hányadosai [37].

Például, ha az alaphang $120 \mathrm{~Hz}$, a szubharmonikusok tartalmazzák a $60 \mathrm{~Hz}(1 / 2), 40 \mathrm{~Hz}(1 / 3)$ a 30 $\mathrm{Hz}(1 / 4)$ frekvenciákat is, egészen $15 \mathrm{~Hz}$ (1/8) értékig [38]. 
Különösen hangszerek esetén van nagy szerepe ennek a spontán létrejövő jelenségnek, mivel azonos frekvencia esetén ennek köszönhetően tudjuk megkülönböztetni az egyes hangszereket, azok hangja alapján.

Egy 389 fö́t vizsgáló kutatás kapcsolatot talált továbbá az érdes hang és a szubharmonikusok jelenléte között is. E szerint az érdesség szintje fordítottan arányos a szubharmonikusok számával, illetve jelentősen függ azok erősségének szintjétől is [39].

A bekezdés elején felvetett ellentmondást az oldja fel, hogy a hallószervünkkel valóban nem vagyunk képesek infra-tartományban érzékelni, de az agyunk képes elöállítani az ilyen hangok érzetét, ezáltal bizonyos frekvenciákat akár „hallhatunk” is általa.

\section{Védekezés a nem kívánt infrahangok ellen}

Ismerve az esetleges hatásait, az emberben joggal merül fel a védekezés gondolata az infrahanghatások ellen. Ehhez érdemes lehet tudni az infrahangok megengedhető felső határait:

- $20 \mathrm{~Hz}-120 \mathrm{~dB}$

- $2 \mathrm{~Hz}-130 \mathrm{~dB}$

- $0,2 \mathrm{~Hz}-140 \mathrm{~dB}$

Az emberek leginkább autóban és vonatban vannak ezeknek a hangoknak kitéve: ott akár $140 \mathrm{~dB}$ is lehet a vibráló szerkezet miatt elérhető érték, és az arra érzékenyeknél ez is közrejátszhat az utazáskor fellépő rosszullétekben. A kis frekvenciákkal szemben az egyéni érzékenység nagyon különböző.

Az ellenük való védekezés legjobb módja a megelőzés az épületek és gépek tervezése során. A modern gépjárművek infrahang-keltését például a szélvédő ablaküveg dőlési szögének megváltoztatásával csökkentették, így áramvonalasabb lett az autó, ezért csökkent az áramlási ellenállás, kevésbé keletkeznek az autó körül légörvények, melyek infrahangokkal járnának [5].

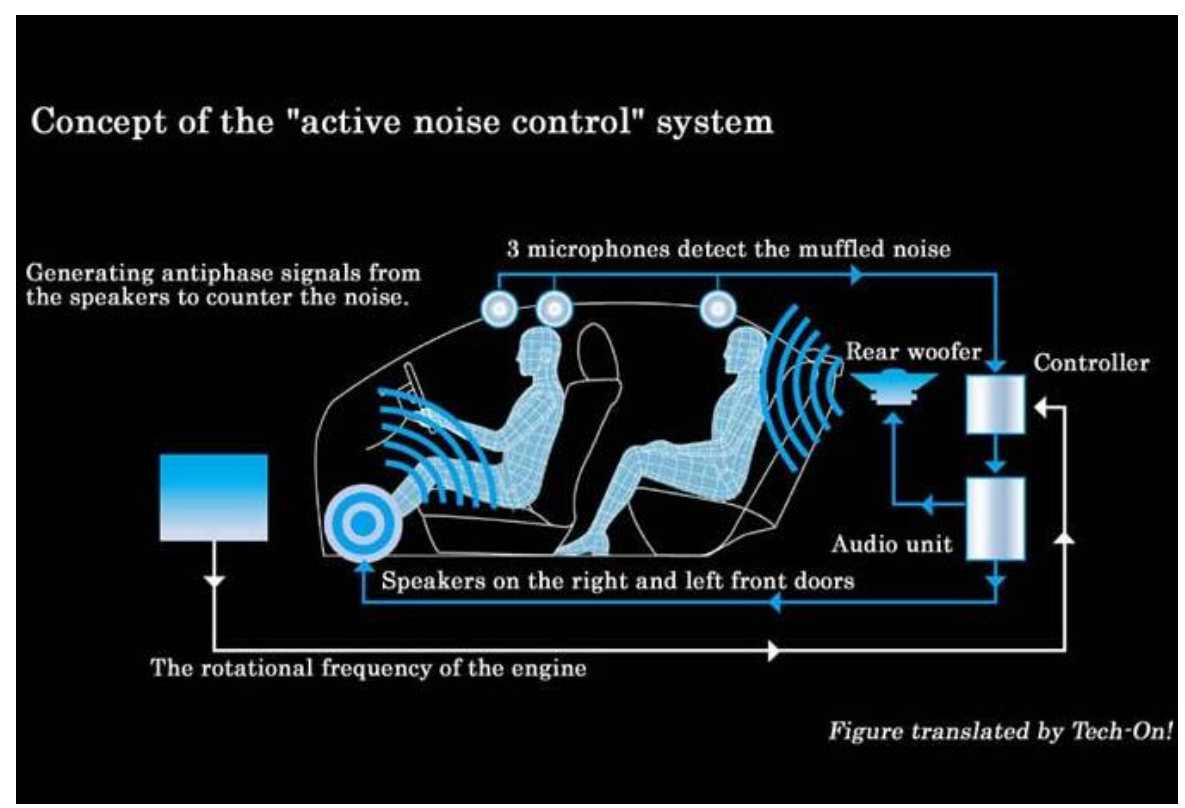

15. ábra. Aktív zajszürés autókban [40] 
Mivel a hagyományos hangszigetelés nem véd a nagyon mély - $50 \mathrm{~Hz}$ alatti - hangok ellen, így létrehozták az aktív zajtompító rendszereket, amelyek többek között ezeket a mély hangok szigetelésével kapcsolatos problémákat oldják meg. Müködési elvük, hogy a megfelelö berendezéssel a zavaró hangokat érzékelik, rögzítik valamilyen átmeneti adattárolón, majd olyan ellenkező fázisú hangokat bocsátanak ki, amelyek az előbbieket elméletileg kioltják. Tudvalevő azonban, hogy a gyakorlatban a tökéletes kioltás nem lehetséges. Ezeket a rendszereket sikeresen használják már fülhallgatókban, gépkocsikban és repülögépekben is.

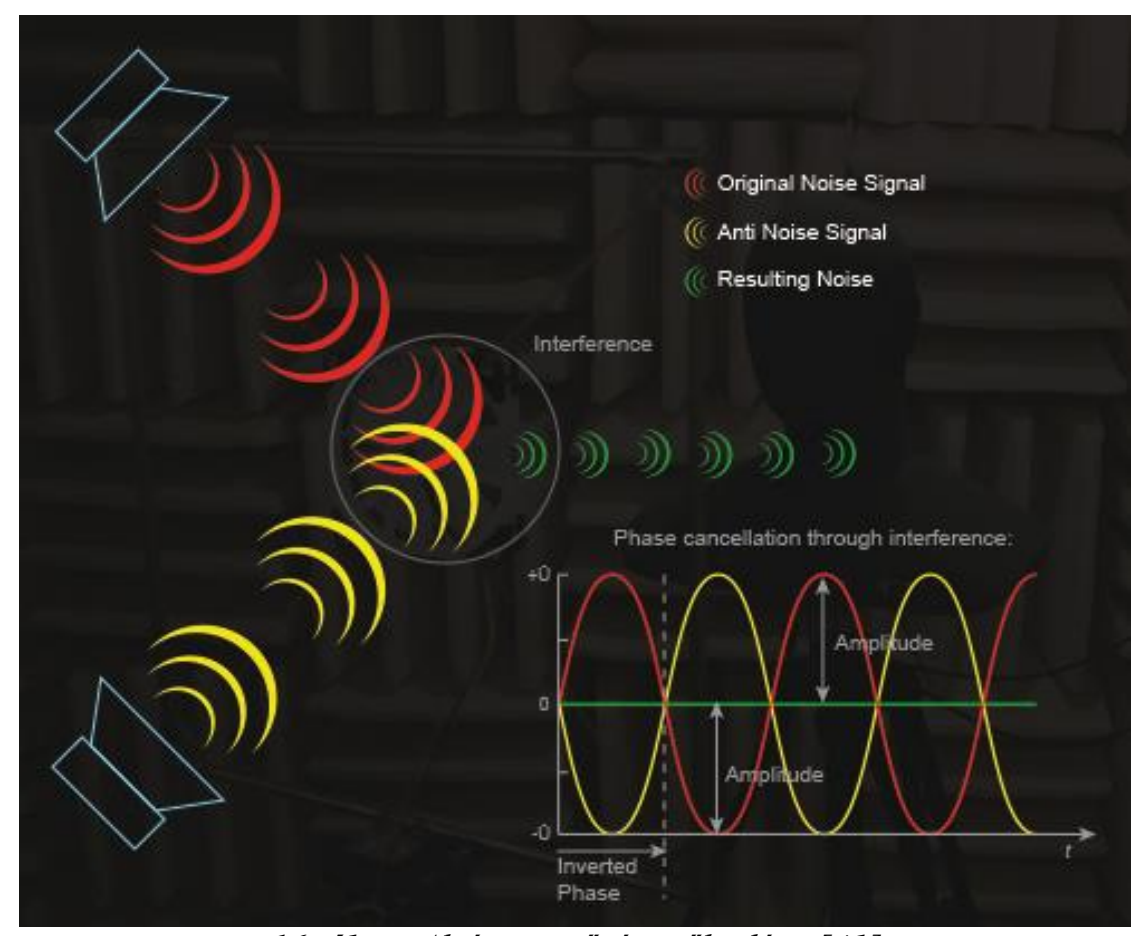

16. ábra. Aktív zajszürés müködése [41]

\section{3. Összefoglalás}

Mostanra talán már felismerhettük, hogy valóban az életünk legkülönfélébb területein kerülhetünk kapcsolatba az infrahangokkal. Amennyiben megmagyarázhatatlan rosszullétet, fáradtságot tapasztaltunk, és az esetleges orvosi vizsgálatok is negatív eredményt hoznak, okkal gondolhatunk erre is kiváltó okként, különösen, ha csak konkrét helyeken, például a lakásunkban, autónkban vagy munkahelyünkön jelentkezik. Ekkor érdemes lehet méréseket végezni az esetleges infrahangok felderítésére.

Mivel a különböző frekvenciájú hangok az élet szinte minden területét átszövik, javasolt, hogy ha hallani nem is halljuk öket, de legalább lássunk velük kapcsolatban tisztán! 


\section{Köszönetnyilvánítás}

A cikkben ismertetett kutató munka az EFOP-3.6.1-16-2016-00011 jelủ „Fiatalodó és Megújuló Egyetem - Innovatív Tudásváros - a Miskolci Egyetem intelligens szakosodást szolgáló intézményi fejlesztése" projekt részeként - a Széchenyi 2020 keretében - az Európai Unió támogatásával, az Európai Szociális Alap társfinanszírozásával valósul meg.

\section{Irodalom}

[1] https://hu.depositphotos.com/51911419/stock-illustration-sound-wave.html (letöltés dátuma: 2019.10.02.)

[2] http://fizikaiszemle.hu/archivum/fsz0708/mester0708.html (letöltés dátuma: 2019.10.04.)

[3] http://infrasoundinvestigation.blogspot.com/2011/12/infrasound-101.html] (letöltés dátuma: 2019.10.04.)

[4] https://tudasbazis.sulinet.hu/hu/szakkepzes/kornyezetvedelem-es-vizgazdalkodas/zaj-esrezges/egyeni-es-kollektiv-vedelem/hallasvizsgalat-folyamata (letöltés dátuma: 2019.10.02.)

[5] https://tudasbazis.sulinet.hu/hu/szakkepzes/kornyezetvedelem-es-vizgazdalkodas/zaj-esrezges/a-zaj-es-rezges-elettani-hatasai/infrahangok (letöltés dátuma: 2019.11.08.)

[6] https://www.translatorscafe.com/unit-converter/de/calculator/sound-intensity-level/ (letöltés dátuma: 2019.11.08.)

[7] https://ntp.niehs.nih.gov/ntp/htdocs/chem_background/exsumpdf/infrasound_508.pdf (letöltés dátuma: 2019.11.08.)

[8] https://napidoktor.hu/termeszetesen/mi-az-a-sonoterapia/ (letöltés dátuma: 2019.10.12.)

[9] https://sonoterapia0.webnode.hu/ (letöltés dátuma: 2019.10.12.)

[10] http://fizikaiszemle.hu/archivum/fsz0708/mester0708.html (letöltés dátuma: 2019.10.02.)

[11] http://skepdic.com/infrasound.html (letöltés dátuma: 2019.10.05.)

[12] https://apps.dtic.mil/dtic/tr/fulltext/u2/a030476.pdf (letöltés dátuma: 2019.10.15.)

[13] https://web.archive.org/web/20110719082026/http://www.psy.herts.ac.uk/ghost/ghost-inmachine.pdf (letöltés dátuma: 2019.10.15.)

[14] Vic Tandy (July 2000). "Something in the cellar". Journal of the Society for Psychical Research. 64.3 (860). (letöltés dátuma: 2019.10.18.)

[15] https://www.cnet.com/news/dolby-atmos-why-its-cool-how-it-works-and-how-to-getit/Research. 64.3 (860). (letöltés dátuma: 2019.10.18.)

[16] https://www.atlasobscura.com/articles/how-the-hidden-sounds-of-horror-movie-soundtracksfreak-you-out (letöltés dátuma: 2019.10.02.)

[17] https://royalsocietypublishing.org/doi/full/10.1098/rsbl.2010.0333?sid=abc27190-5718-4623b4c9-65f5d0918eb2 (letöltés dátuma: 2019.10.02.)

[18] https://nofilmschool.com/2017/06/disquieting-uses-infrasound (letöltés dátuma: 2019.10.02.)

[19] https://en.wikipedia.org/wiki/Infrasound (letöltés dátuma: 2019.10.12.)

[20] https://www.weather.gov/jetstream/dart_max (letöltés dátuma: 2019.10.19.)

[21] https://phys.org/news/2018-05-decoding-tornadoesinfrasound.amp?fbclid=IwAR14308gbJcSGUYCBExURJ_mkY_zyrrbKBd4fA4yu7KD6QKCY DxwIoecTEc (letöltés dátuma: 2019.10.22.)

[22] http://hadmernok.hu/152_09_megyeril.pdf (letöltés dátuma: 2019.10.22.) 
[23] https://www.geekslop.com/2017/use-effects-military-acoustic-weapons-infrasonic-sonicultrasonic-frequencies (letöltés dátuma: 2019.10.02.)

[24] https://www.mirror.co.uk/news/world-news/mystery-bermuda-triangle-deepens-dangerous10714990 (letöltés dátuma: 2019.10.04.)

[25] https://www.origo.hu/tudomany/20170617-akar-halalos-fegyverkent-is-alkalmazhato-azemberi-ful-szamara-hallhatatlan-infrahang.html] (letöltés dátuma: 2019.10.13.)

[26] https://www.thetravel.com/25-little-known-facts-about-the-dragons-triangle/ (letöltés dátuma: 2019.11.06.)

[27] https://www.maritimemanual.com/devils-sea-dragons-triangle/ (letöltés dátuma: 2019.11.06.)

[28] https://impressmagazin.hu/stresszt-okoz-a-hatterzaj/ (letöltés dátuma: 2019.10.02.)

[29] https://www.iflscience.com/environment/real-science-wind-farms-noise-infrasound-and-health/ (letöltés dátuma: 2019.10.08.)

[30] https://24.hu/kozelet/2019/09/29/megujulo-energia-konteo-astroturfing/ (letöltés dátuma: 2019.10.08.)

[31] http://www.na-paw.org/pr-141109.php (letöltés dátuma: 2019.10.12.)

[32] https://www.hazipatika.com/napi_egeszseg/egeszsegugy/cikkek/meghokkento_velemeny_a_sze lturbinakrol/20190408120121 (letöltés dátuma: 2019.10.02.)

[33] https://stopthesethings.com/2019/05/07/far-out-german-study-finds-pulsing-wind-farminfrasound-20-kilometres-from-turbines/ (letöltés dátuma: 2019.10.16.)

[34] https://journals.sagepub.com/doi/pdf/10.1260/026309205775374451 (letöltés dátuma: 2019.10.16.)

[35] https://imagazin.hu/hallani-nem-letezot/ (letöltés dátuma: 2019.10.16.)

[36] http://www.basszusgitar-gitariskola.hu/basszusgitar_zene_konszonancia_felharmonikus.html (letöltés dátuma: 2019.10.02.)

[37] http://bitepito.hu/rejtveny/index.php?searchinput=szubharmonikus (letöltés dátuma: 2019.10.04.)

[38] https://en.m.wikipedia.org/wiki/Undertone_series?fbclid=IwAR28e7qlgaIqDR6H5rWLaYouG2 9L2KWwNNmo8eWXcT93fBWGf7oyBqLSuNI\#cite_note-Dallos-2 (letöltés dátuma: 2019.10.06.)

[39] https://www.sciencedirect.com/science/article/pii/S0892199797800227?via\%3Dihub (letöltés dátuma: 2019.10.06.)

[40] https://www.techradar.com/news/car-tech/noise-cancelling-tech-comes-to-car-interiors39874510714990 (letöltés dátuma: 2019.10.16.)

[41] https://noctua.at/en/noctua_anc_project (letöltés dátuma: 2019.11.08.) 